\title{
COCA-COLA, MARLBORO, SUZUKI: TURBOFOLK MUSIC AS A TOOL OF POLITICAL PROPAGANDA DURING THE 1990S IN SERBIA
}

\section{Martina Plantak}

Andrassy University Budapest, Hungary

E-mail:martina.plantak@andrassyuni.hu

\begin{abstract}
This paper analyzes the relationship and correlation between propaganda and the mass media on the example of turbo-folk music as the most influential cultural model in the 1990s in Serbia. The purpose of this paper is to examine the influence and spread of turbo-folk music through various propaganda techniques and through the mass media. The primary aim of the research is to understand the related propaganda and the media, while the starting hypothesis is that turbo-folk music served the political interests of the ruling elites as a distraction from the gloomy political and economic situation in which Serbia was. My intention is that turbo-folk music could be considered as the primary cultural model of that age, just as much as the culture of escapism.
\end{abstract}

Key words: propaganda, mass media, turbo-folk, culture, political communication, Serbia

\section{Introduction}

The image of Serbia in the 1990s was far from desirable. With the breakup of Yugoslavia and the war in Croatia and Bosnia and Herzegovina, Serbia was subject to sanctions, hyperinflation, poverty, and crime. In material and moral hopelessness and with the change of the ruling elite, a new culture emerged. What was previously a marginal subculture from the largely rural areas of the country in the 1990s fiercely entered into the mainstream and became the dominant cultural model of Serbia.

When many Serbs were mobilized and forced to fight on the Croatian and Bosnian fronts; while rock and other alternative subcultures were pushed out of the scene, turbo-folk, with its distorted moral values, and the kitsch it offered, needed to animate the public and to become a distraction from the harsh reality they were in. Although considered apolitical, especially because of the content it offered, turbo-folk music served the political interests of the 
ruling elites as a distraction from the gloomy political and economic situation in which Serbia was and therefore could be considered as the primary cultural model of that age, just as much as the culture of escapism.

The first part of the paper will define the term "turbo-folk," while the second part aims to define the relationship and mutual correlation of propaganda and the mass media. The third part of the paper analyzes turbofolk as a cultural pattern of that time, while the last part is devoted to music and its influence on the wider mass with the two given examples. From these examples, it will be shown that turbo-folk music opposed to other music genres, held a privileged position, respectively, was working for the ruling elite.

\section{The Definition of Turbo-folk}

Turbo-folk can be described as a genre of music with the elements of both western and eastern music. It can be seen as a combination of two words with completely different meaning, where, according to Kronja $(2004,103)$ "figuratively, 'turbo' referred to a challenge, speed, fearlessness and participation in the upcoming, fashionable trends, ascribed to turbo-folk artists and audience, while 'folk' signified that 'turbo-folk' represents one of the genres of Serbian popular, folk music."

Uroš Čvoro $(2014,56)$ gives a similar explanation, stating that "turbo-folk is high-energy pop mixed with traditional folk music. It borrows elements of oriental and Mediterranean melodies that are channeled through electronic dance rhythms and fused with MTV-style video presentation. The music's performers are predominantly scantily clad, sexually provocative women singing about love, passion, death, sex and money." Turbo-folk can also be described "more as a conceptual category that aggregates connotations of banality, foreignness, violence and kitsch in order to provide a critical apparatus with a ready-made strategy of distancing." (Baker 2007, 139) Eric Gordy, in his study of culture in Serbia in the 1990s, stated that turbo-folk played an important role in legitimizing the Milošević regime, deriving his genealogy from a "return" to a rural socio-cultural context contrasted with urban rock music (Gordy, 1999). Katerina Luketić $(2013,400)$ states, that "from the beginning of the nineties' neo-folk scene began to promote herselfas a hidden state project - into a most massive Serbian cultural model. Milošević and his politicians were trying with all sorts of strategies, especially with the control of their media, in order to eliminate all other cultural models, which could cause anti-regime critics or individually, by opening the door to turbo-folk, the culture of oblivion, emotional emptying, and a celebration of 
populism and crazy parties." For this reason, turbo-folk is seen as escapist, mass, and entertainment culture - in the first hand, paradoxically assimilated and later promoted nationalism, and patriotism and became the most powerful subculture of war. Because of the so-called political disengagement, turbo-folk was a culture that accepted everybody, from war criminals and profiteers to murderers and nationalist. "Therefore, turbofolk is a culture of retardation, extremely populistic and socially unengaged." (Luketić 2013, 400-404)

Đurković $(2003,2)$ highlights two processes that were relevant to the formation of the turbo-folk:

a) the country lost a dictator of cultural policy and since then the market has been one that dictated the musical taste. Thus, "the new mainstream was created on a low budget system";

b) process of simultaneous physical isolation of the country from the outside and internal musical opening - people could not physically enter or leave the country, but they could use the new technological revolution (Internet, satellite television) to get closer to the patterns of Western popular culture.

Besides that, Đurković $(2003,3)$ distinguishes three positions that have emerged about the turbo-folk:

a) The view of traditionalists, cultural conservatives and self-proclaimed nationalists who see in turbo-folk and in its oriental rhythms the attack of Islam on the Serbian spiritual tradition and consider that the communist authorities deliberately introduced "Asian rhythms" into the Serbian music scene.

b) The viewpoint of globalists and cosmopolitans who see a great danger in the turbo-folk and see it as "a nationalist product by which Milošević deliberately destroyed rock ' $n$ ' roll, which by them is an urban matrix of music that everyone in Serbia should listen to."

c) The position of the new Trotskyist left, which is contrary to the first two and treats their members as cultural racists because they oppose the oriental elements in the turbo-folk. Members of the new Trotskyist, left approve of the turbo-folk as they see it as a fusion of everything that globalization and progress in Serbia represent.

As already stated, turbo-folk is also very often viewed as a covert machine of Milošević's propaganda system, which was supposed to be a distraction from the overall bad state of the country. As Kronja highlights:

"Moreover, these musical genres and their total media presentation proved themselves to be one of the most powerful ideological weapons of Miloševićs regime. Forming a popular culture counterpart to the unscrupulous ideological 
propaganda of RTS (RadioTelevision of Serbia), which used nationalist and chauvinist rhetorics to justify and support involvement of Serbia in civil wars in Croatia and Bosnia, and later in Kosovo, turbofolk and dance music promoted the life-style and system of values of the new Serbian elite formed during the nineties: regime politicians, war-profiteers, criminal bosses turned into "businessmen" and glamorous turbo-folk stars, mainly highly eroticised female singers. This system of values aimed to establish the cult of crime and violence, war-profiteering, national-chauvinism and provincialism, with the abandonment of morals, education, legality, and other civic values." (Kronja 2004, 103)

\section{Social and Political Context of the Rise of Turbofolk}

"Folk is people, a turbo is a pressurized injection system into an internal combustion engine cylinder. Turbofolk is a burning nation. Any enhancement of this combustion is turbofolk, stirring up the lowest passions in Homo sapiens," emphasizes in his song "Turbofolk" the famous Montenegrin singer Antonije Pušić, known to the wider audience as Rambo Amadeus, who is also the creator of this term.

With the death of Josip Broz Tito, already in the early 1980s, there were intensified national and ethnic turmoil in Yugoslavia, a weakening of the economy and, consequently, an increasing opening to the West and the culture it promoted. The former Yugoslav socialist society was increasingly beginning to open to Western media and Western values, thereby becoming an active consumer of the above-mentioned culture.

Television, as the primary medium of that period, was given the role of political-social center of power, and therefore a medium used for propaganda purposes. Hence, the very beginning of turbo folk music is closely linked to the process of transition of a socialist society to the capitalist. With the change of the economic system and the turning of the Yugoslav society, there were increasing ethnic conflicts and strengthening of national issues and identities in the territory of the Yugoslav republics, which have been reflected in all spheres of Yugoslav political culture, including in the popular culture and media.

This is precisely what served the then president of Serbia, Slobodan Milošević, to promote his repressive regime through media that was mostly owned and controlled by his immediate family members or close relatives from the Serbian elite. (Kronja 2004, 105)

According to Rasmussen (in Dumančić and Krolo 2017, 159), this genre was created to meet the cultural needs of rural populations that came to 
urban areas and to address the impact of the rural environment while at the same time lacking the willingness to embrace the urban cultural model. The precursor of the turbo folk was the newly composed folk music that could be heard most often in rural parts of Serbia, while the turbo folk, as its successor, with its elements of simplicity of text and fun character, and yet with its modern western production, could serve as an excellent screen for the society in transition and consequently to Miloševićs regime.

Gordy $(2004,560)$ states that turbo folk became a dominant culture which, in addition to the entertaining character that would remove the social and political problems of the Serbian public, promoted the elitist values of the Serbian elite and the ideas of national unity, warrior culture and patriotism. With media such as "Radio Ponos", "Palma TV", or the much popular and profiled "PINK TV", neofolk culture with turbo folk as its primary product was slowly and surely gaining in importance and has eventually become a major political culture model in Serbia. Kronja cites as an example that TV Pink, in addition to production companies ZAM (Zabava miliona) and Grand, all owned by Serbian oligarchs, monopolized the media space and squeezed rock and pop music to the margins of culture (Kronja 2004, 106). Furthermore, according to Gordy $(2004,572)$ TV Pink's entertainment program promoted the rich Western lifestyle enjoyed at the time by people close to the regime, criminals and war profiteers who privatized state property and blamed poverty and the collapsed economy western powers and domestic traitors.

\section{The Cohesion of Propaganda and Mass Media}

The role, the power, and the influence of mass media are needed. Splichal $(1975,3)$ emphasizes that "economic and social development and industrial revolutions had the greatest impact on propaganda, and its greatest role was played by the mass media and the mass public." Quite similar, and baring in mind that one of the basic features of propaganda are intent, communication and attempt to influence people (Qualter, 1962), propaganda can also be seen as one of the ways of usage of political communication.

Following Vreg $(2000,18-20)$, political communication is an interaction that takes place within the area of political action between two or more political actors. The basic interaction involves more straightforward media sphere and political publicity. By this, political communication enables the expression of the opinions, attitudes, needs and interests of different social groups, and justifies the political correlation function. Habermas $(2006,415)$ states that political communication goes from the bottom up and from the top down through the multi-level system that occurs in various forms and spaces. 
It includes everything from everyday conversations in society, public discourse and mediated communication in the public to institutionalized discourses in the center of the political system. It is through the development of mass media in the 20 th century that they become the main communication channel of political communication.

According to Ivan Šiber $(1992,9)$, the concept of propaganda is again found at the beginning of the 20th century, with the development of market production and consumption, or the development of parliamentary democracy and mass communication. Today, the author continues, "has become an integral part of every thoughtful action in all areas of social life." (Šiber 1992, 9) The use of mass media, public addressing of political actors, the use, and exposure of slogans, posters and other features can be attributed to both political propaganda and modern pre-election campaigns. Both forms of political communication try to change the views and behaviors of the electorate through pressures or convictions through the media, but only political propaganda starts with more aggressive psychological manipulation. Because of this, communication is based on an unequal and one-sided basis. (Spahić 2000, 61).

Propaganda can also be divided by our attitude to reality, namely white, black and gray propaganda. The white propaganda data are real. Especially in crises, this form is rare as it can have the opposite effect. Black propaganda data can be fabricated. It generally has a great effect, but if the lie is revealed, the effect is negative. Gray propaganda selects otherwise true information that is most relevant in a given situation. She suppresses the unfavorable information, while exaggerated with the positive ones. Although the source of the information is concealed, people are more likely to believe in this propaganda than the white one. (Pečjak 1995, 135-140). Given the openness of goals and the directness of action, we distinguish open, delayed and indirect propaganda. With open propaganda, the goals are known. Delayed propaganda creates the right atmosphere for the upcoming propaganda campaign (Vreg 2000, 120).

According to Splichal, for its subject matter, what propagandists are propagating and what real social processes are propaganda matching or trying to transcend, propaganda can be classified into three basic categories:

1. political

2. economic

3. cultural (propaganda of a particular type of culture) (Splichal 1975, 62). Therewithal, mass media can also be a means of manipulation or propaganda. As Reiner Geißler highlights, media can also have a rather stabilizing effect on the audience, especially in the terms of "depoliticisation" of the content. 
According to him, this depoliticisation can be seen through two types of manipulation: first, certain elite occupies the mass media, and second, market economy mechanisms (maximization of recipients) produce a non-political mass culture. Here he distinguishes five types of manipulative content:

1. Integrative content without critique of existing social and political circumstances;

2. Lack of placement of individual destinies in the social framework;

3. Politically relevant information is quantitatively irrelevant in relation to the entertainment;

4. The boundaries between information and entertainment have been deleted;

5. Qualitative depoliticisation by if unrelated detailed information without context. (Geißler 1973, 92-93)

There are many other different definitions and stages how propaganda can be described or explained. For example, propaganda can be broken into ten stages when analyzing it in detail. These stages are:

1. the ideology and purpose of the propaganda campaign,

2. the context in which the propaganda occurs,

3. identification of the propagandist,

4. the structure of the propaganda organization,

5. the target audience,

6. media utilization techniques,

7. special various techniques,

8. audience reaction to various techniques,

9. counterpropaganda, if present, and

10. effects and evaluation (Jowett and O'Donnell 2013).

From all the ten above mentioned stages it can be seen that turbo-folk music was a successful tool of political propaganda. Šiber offers similar explanations. According to him, there are certain principles that propaganda, in order to be successful, must be adhered to.

Firstly, the principle which is explaining that the message must be noticed. The task is to isolate the propaganda content from the stimulus context. At least, three elements should be taken into account:

1. Availability of the message, which means that message must reach the recipient. To achieve this, the message should be marketed through many media; to adapt it to the specific conditions of the space, it should be imposed on the viewer with intense colors, sound and movement.

2. Attraction of the message - to attract attention so that the message is accepted. 
3. Intelligibility of the message - every recipient should understend the meaning of a particular message.

Second is the principle of needs, which is divided into biological, material, social and psychological benefits. Principle of value refers to the relation of the message to the value system of the individual, groups and society in general, which directs its behavior, creates the criteria of the desirable and undesirable, while the principle of unpredictable can be devided into:

1. Each propaganda is a kind of action in time, and it is precisely this temporal dimension of propaganda that opens the possibility for significant changes beyond the immediate control of the propagator.

2. Each propaganda is carried out in a competitive situation, which means that it acts side-by-side and often against the propaganda activity of others. (Šiber 1992.)

Šiber also points out some of the propaganda techniques which mostly closely connect with the emotions. The significance of emotions in propaganda activity is enormous. It is the aspect of the human psyche that is most sensitive and appropriate to act. /.../ By provoking certain emotions, prerequisites are created to facilitate the propaganda content, reduce eventual resistance and suppress criticality. Therefore, there are numerous techniques and mechanisms focused on the emotional component of attitude to achieve a faster and more disproportionate propaganda effect (Šiber 1992, 31). The frequent occurrence of some content that is initially neutral to the recipient, along with content to which there is a positive emotional relationship, will lead to a positive attitude towards the neutral content after a certain time. For example, if you hear some song that you do not like on the radio in the morning, after frequently hearing it for the whole day on different media sources, there is a big chance you will be at least whistling it in the evening.

If we skip some other techniques, when it comes to using a turbofolk music as a tool of political propaganda, probably the most powerful one was and still is the use of sexuality and erotica. According to Šiber (Šiber 1992, 32), everything that is attractive is mostly always forbidden and by manipulating differently the need for people to see, hear, feel, at least as a disguised promise, effectively attracts attention, which increases the likelihood of acceptance of the underlying message. "We must not forget about another large group of techniques that Šiber calls techniques that manipulate feelings of vulnerability and insecurity. For instance, the popularity of certain people is also a convenient mechanism for directing and attracting people. Such popular names often lend support to a program, party, or specific candidate." 
If we call turbo folk music an aggressive imposition of politics through propaganda, it should not surprise us why and how easily it came about. According to Šiber, for propaganda to be successfull, she must meet these conditions:

1. The situation of social crisis - when there is a gap between the level of aspirations and the possibilities of achievement, and on the other hand, when it is shown that the existing mechanisms of social regulation cannot resolve the crisis and indicate possible solutions and perspective of development.

2. Crisis of the value system - the breakdown of the existing mental circuit, when there is a cognitive inconsistency between the experience of social reality and the essential internalized value strongholds of the social mechanisms of society.

3. Lack of democratically designed political system - which by its normative solutions enables the formation and expression of different interests and perceptions of social development, which could direct dissatisfaction with social development into the creative search for alternative solutions to the crisis.

Lack of political culture appropriate to a democratic system, which should represent the implicit connective tissue of social relations and tolerant confrontation of different visions of social development. (Šiber 1992, 44) Traditional society, with no experience of democratic order, a distinct dominance of the authoritarian personality structure in the population, was a grateful object of propaganda-directed dissatisfaction (Šiber 1992, 45).

The importance of the media in the propaganda manifestation is precisely on transmitting messages to the masses of people because, as Bennett states, "the media are not separated from social reality, passively reflecting and returning to the world its own image, 'but just supposedly', they are part of social reality, contributing to its contours, logic and direction of its development through the socially articulated way through which media shape our perceptions" (Bennett in Hromadžić 2014, 19).

The most important functions of mass media are that, firstly, the media increase the reputation and authority of individuals or groups by legitimizing their status (status conferral function), secondly, they are reinforcing social norms ("ethicizing function") and lastly, sometimes in certain circumstances, they function dysfunctionally as well that they can cause non-negligence and passivity ("narcotization") (Lazarsfeld and Merton, 1948). Precisely in this passivity, one can see the escapist and, consequently, the entertainment role of the media. Hromandžić (2014) notes that the media are increasingly 
turning to spectacularization and, consequently, the depoliticization of society, devoting more and more to the so-called "celebrity culture."

\section{Turbo-folk as a Product of Popular Culture}

Drawing certain parallels, we conclude that turbo-folk could also be called a culture of spectacle, which can provide the consumer with a certain dose of satisfaction, emotionality and social change along with changing social values. In support of the claim that turbo folk music and lifestyles can be considered as a kind of (sub)culture, Danesi understands culture as a "system that includes beliefs, rituals, performances, art forms, lifestyles, symbols, language, clothing, music, dance and any form of human expressive, intellectual and communicative behavior that is associated with the community over a period of time" (Danesi 2008, 2). Similar, culture can indicate all those activities in which life is realized. And yet, these are also the activities where this happens in the aforementioned forms. Cultural products, therefore, are forms that make life meaningful; they encompass the life course and give it content and form, freedom and order (Simmel 1971, 375).

The primary question that arises here is, why was turbofolk music such a great means of propaganda and manipulation through the mass media, and second, how did it become and remain so successful?

According to Kronja (Kronja 2004, 106), it was a "massive, overwhelming spectacle which included intended ideological messages into style, iconography and visual presentation of turbo-folk music, as well as into its lyrics." The main channel of promotion of the turbo-folk and dance image, which contributed to the creation and establishment of turbo-folk style as a dominant mass culture and popular culture style in Serbian media during the 1990s, was the music video. Erotically provocative photographs of turbo-folk female stars in magazines and the tabloid press, as well as all the entertainment TV-shows, many of them going "live", also established and celebrated the style which was widely accepted and imitated among Serbian youth but also among representatives of the new "business" class and ruling politicians (Kronja 2004, 107).

The primary task of the mass media was to distract the audience from the daily monotony and grayness of Serbia at that time, which was sinking in sanctions, poverty and inflation. In other words, political and economical situation back then in Serbia, could be described as situation of social crisis, without a democratically designed political system and with a complete decay of cultural and moral values. In these terms, it was quite easy for propaganda machinery to impose turbo-folk music together with all its values to become 
a dominant cultural model. Guided by the slogan "panem et circenses", kitsch as a concealed nationalism became the main path of popular culture in Serbia. From a rural deprivileged cultural direction which came from primarily peripheral and rural parts, with the change of the ruling elite, this culture became the dominant cultural model of Serbia. Or, how Kronja describes it: "a new militant subculture of criminal youth, drug-dealers, war-veterans, thugs, 'dieselmen' (macho guys in diesel jeans, wearing large golden chains and tracksuits), 'sponsored girls', another desperate youngsters, were the main protagonists and the audience for production and consumption of turbo-folk sound, as, for them, a perfectly suitable combination of nationalist ideas, due to its national folk musical origins, and aggressive, macho and criminal attitudes, found in rap and hip-hop rhythm and its visual presentation." (Kronja 2004, 106)

According to the representatives of theories of popular and mass culture, this culture cannot be in a positive context, while her only purpose is to distract attention from the problem. "Mass culture is a popular culture that is produced with mass-produced industrial techniques and marketed to the mass market for profit" (Strinati 1995, 10). Namely, it is defined by the hierarchical pinnacle of political power and capital, while individuals are viewed as ordinary consumers and passive consumers of that same culture. "From the point of view of producers of popular culture, there is no mass audience, but only segments of the differentiated and stratified market are expressed in tastes, values and preferences, as well as money and power" (Strinati 1995, 49).

Turbo-folk with its glamorous erotic-charged videos, in which eroticised women in tight-fitting dresses and with lots of make-up sing mostly about love and having fun, definitely attract the attention of a wider audience, especially when these videos can be seen on almost all national programs. In fact, on certain television channels such as PINK TV or Palma TV, information programs have not existed at all; between glittering and kitschy turbo-folk videos, occasionally one could find some Mexican soap operas or so-called "clairvoyants" who lively predicted the future of viewers. Also, with simple and memorable song verses, the message was much easier to reach a wider audience. Singing about the "turbo" fast, modern and western way of life where everything is allowed and in which entertainment does not stop, the audience was distracted by the harsh reality and was impeded of a critical reflection on the economic and political situation of the country.

Another reason why turbo-folk was so popular was because it could be characterized as a hybrid of foreign and domestic, that is, both mass and folk culture. Following Adorno and Horkmeier, mass culture is produced by 
political and banking lobbies that alienate consumers from their real needs and mold them to deprive them of their individuality. With the help of the mass media, the powerful elite create and distribute cultural products to achieve their own interests. Consumers are perceived as passive, alienated mass audiences who, without thinking and critical retreat, accept whatever is imposed on them (Horkheimer and Adorno, 1979). But even though it was produced and imposed from the political and state elite, turbo-folk music, as the name says, also had its folk part, which has greatly helped in embracing this type of music, especially among the rural population. Folk culture comes from the people and is the culture that the people create by their own needs, without the influence of high culture. "Folk culture, unlike popular culture, is the product of a relatively stable, traditional social order, in which social differences are not a conflict of nature, and therefore distinguished by social consensus rather than social conflict" (Fiske 2001, 236). Turbo-folk, music seen as a hybrid of popular and folk music, evolved mostly from folk music and with time has taken on modern western music patterns. For this reason, turbo-folk can still satisfy so-called basic instincts of audience, while, it can offer them eroticised western and modern production.

\subsection{The Role of Turbo-folk Music}

As Muršič stresses, "music is arena of constant political struggle in the cultural sphere" (Muršič 1999, 178-185), while also adverting that we should be aware that every music is politcal as well as public activity. Music is a medium that unites like-minded and for this reason, music can be dangerous to regimes that do not tolerate differences; adding that music embodies the spirit of some group, but can also awaken national and nationalistic feelings (Muršič 1999, 178-185). Music can reach out to different types of people and groups and allow them not only to listen, but also to be heard. This statement can be better illustrated in the example below.

During the war in Croatia and Bosnia and Herzegovina, in Serbia was formed a project called Rimtutituki, with which a few popular rock groups have openly opposed the Serbian government. In a time when Serbia was transforming in the neofolk empire of Milošević's propaganda apparatus, this project should have alerted on newly - formed war situations, disapproved by many citizens.

In the lobby of the Student Cultural Center (SKC), in Belgrade, this groups have decided to make a single that will be spreading anti-war propaganda. They have composed a song called "Listen here (peace brother, peace) ${ }^{1}$ ",

\footnotetext{
${ }^{1}$ Slušaj vamo (mir brate, mir).
} 
which should, with anti-war lyrics, invite the general public to commit against the war. The Milošević's government immediately banned the public gathering and the performance of this song. While this anti-war project was banned, turbo-folk songs and videos could be seen in almost every state media.

The dominance of turbo-folk over other musical genres, can be seen in another example. During the NATO bombing of Belgrade and Serbia, the political propaganda was at its highest. With the patriotic songs made especially for the occasion, the song that stood out the most was surely "we love you our fatherland 2". With the patriotic lyrics such as your name is within our hearts, and the army marches, it was quite easy to raise the moral and to awake the national feeling in the people.

A second strategy from a well-organized state propaganda was in holding concerts on squares and bridges during the bombing. In the first few days, the squares were crowded with thousands of people soundly opposing and protesting the NATO bombing. Different musicians alternated on the stage, from pop and turbo-folk singers to rock musicians. And for instance, while some of the artists were singing in English, with the intention of clarifying the situation to people abroad, turbo-folk musicians have been there mostly simply to entertain the crowd and to distract them. After only two days, the only performers on the stages were turbo-folk singers, who, mostly apolitical, singing about luxury, passion, and love to their homeland, were not considered to be a political threat. Likewise, even though the number of people protesting has shrunken greatly over the days, national television still only aired the footage of the first few days so as to mislead the masses into believing that the protest is even stronger than it was before. The situation in which NATO forces are bombing Belgrade, while the nation is singing famous Serbian song "No one can harm us, we are stronger than the fate", can at least be considered ironic. A lot of people really believed that no harm can be done to them, if they proudly protest by singing and that they can honestly, again, just by singing, win the war. The irrationality of this protest, which was under the influence of state media was visible, but still inexplicable.

2 Volimo te otadžbino naša. 


\section{Conclusion}

Propaganda is always closely linked to the media, while political propaganda can often be called political communication through the mass media. The aim of this research was to determine whether the turbo-folk musical direction, with the cultural and moral values it propagates, was the product of political propaganda by the ruling elites.

Through Geißler's five directions of media manipulation, it was established that turbo-folk served to entertain and distract the public from the political and economic situation in the country. Information programs have been replaced with entertainment channels, the boundaries between information and entertainment have been blurred, while politically relevant information has become irrelevant to entertainment.

Šibers conditions were also fulfilled, because there was a situation of social crisis, a decline in moral values, and political cultures and democracies. In such an environment, with the help of a state apparatus, turbo-folk music easily becomes the dominant cultural model. As a means of sedation and distraction, turbo-folk, through their values, completely turn the cultural image of Serbia and represent war, crime, luxury, and a fast way of living as the new cultural dominant. Immersed in such a lifestyle, surrounded by censorship and blockade of foreign media, Serbian society embraced this lifestyle and integrated easily with it. Turbo-folk, while inherently apolitical, becomes subject to political propaganda and mass manipulation by the state leadership. With its simple and catchy lyrics and erotic videos, promoting fast and luxurious lifestyles, turbofolk can also be understood as a culture of spectacle and culture of escapism.

We can state that turbo-folk has fulfilled its default role as a distraction from social and economic situation in the country, but that would not be possible without the interference of propaganda through mass media. At that time in Serbia, turbo-folk has fulfilled all three categories of propaganda, respectively, political, economic and cultural.

\section{References}

Baker, Catherine. 2006. "The Politics of Performance: Transnationalism and its Limits in former Yugoslav Popular Music, 1999-2004." Ethnopolitics 5 (3): 275-293.

Čvoro, Uroš. 2014. Turbo-folk Music and Cultural Representation of National Identity in former Yugoslavia. Surrey: Ashgate publishing. 
Danesi, Marcel. 2008. “Popular culture: introductory perspectives.” Lanham: Rowman \& Littlefield.

Dumančić, Marko, Krolo Krešimir. 2017. "Dehexing postwar west Balkan masculinities: The case of Bosnia, Croatia and Serbia, 1998 to 2015." Men and Masculinities 20(2): 154-180.

Đurković, Miša. 2003. Ideološki i politički sukobi oko popularne muzike u Srbiji (Ideological and political conflicts over popular music in Serbia). http://instifdt.bg.ac.rs/wp-content/uploads/2004/09/M. Djurkovic.pdf. Accessed June 22, 2019.

Fiske, John. 2001. Popularna kultura (Popular culture). Beograd: Clio.

Garth S. Jowett, Victoria O'Donnell. 2014. Propaganda and Persuasion. SAGE Publications.

Geißner, Ranier. 1973. Massenmedien, Basiskommunikation und Demokratie (Mass media, Basic communication and Democracy). Tübingen: Mohr.

Gordy, Eric D. 1999. The Culture of Power in Serbia. Nationalism and the Destruction of Alternatives. University Park: Pennsylvania State University Press: $104-105$.

Habermas, Jürgen. 2006. "Political Communication in Media Society: Does Democracy Still Enjoy an Epistemic Dimension? The Impact of Normative Theory on Empirical Research." Communication Theory, 411-426. http://onlinelibrary.wiley.com/doi/10.1111/j.14682885.2006.00280.x/pdf. Accessed May 3, 2019.

Horkheimer, Max, Theodor W. Adorno. 1989. Dijalektika prosvjetiteljstva. (Dialectics of the Enlightenment). Sarajevo: Veselin Masleša - Svjetlost.

Kronja, Ivana. 2004. "Turbo Folk and Dance Music in 1990s in Serbia: Media, Ideology and the Production of Spectacle." The Anthropology of East Europe Review 22 (1): 103-114.

Lazarsfeld Paul, F., Robert K. Merton. 1948. Mass Communication, Popular Taste and Organized Social Action in Mass culture. 
http://www.irfanerdogan.com/dergiweb2008/24/13.pdf. Accessed June 22, 2019.

Luketić, Katarina. 2013. Balkan od geografije do fantazije (Balkan from geography to fantasy). Zagreb, Mostar: Algoritam.

Muršič, Rajko. 1999. Pop music in the claws of reviews and censorship. Forbidden fruits of music: 179-199.

https://www.dlib.si/stream/URN:NBN:SI:DOC-T6EWVRAT/bc909cc52415-4272-8278-31798e9a7118/PDF. Accessed March 1, 2018.

Pečjak, Vid. 1995. Politična psihologija (Political psychology). Ljubljana: selfpublishing.

Qualter, Terence H. 1962. Propaganda and Psychological Warfare. New York: Random House.

Sav taj folk (All that folk) 2004. TV B92 Serbia.

Simmel, Georg. 1971. Georg Simmel on Individuality and Social Forms: selected Writings. Chicago: The University of Chicago Press.

Splichal, Slavko 1975. "Raszežnosti političke propagande (Dimensions of political propaganda)". MA thesis. Fakulteta za družbene vede: Ljubljana. 